University of Nebraska - Lincoln

DigitalCommons@University of Nebraska - Lincoln

\title{
Landform, soil, and plant relationships to nitrate accumulation, Central Nevada
}

W.D. Nettleton

USDA, NRCS, NSSC, dnettleton@inebraska.com

F.F. Peterson

University of Nevada - Reno

Follow this and additional works at: https://digitalcommons.unl.edu/usdaarsfacpub

Part of the Agricultural Science Commons

Nettleton, W.D. and Peterson, F.F., "Landform, soil, and plant relationships to nitrate accumulation, Central Nevada" (2011). Publications from USDA-ARS / UNL Faculty. 866.

https://digitalcommons.unl.edu/usdaarsfacpub/866

This Article is brought to you for free and open access by the U.S. Department of Agriculture: Agricultural Research Service, Lincoln, Nebraska at DigitalCommons@University of Nebraska - Lincoln. It has been accepted for inclusion in Publications from USDA-ARS / UNL Faculty by an authorized administrator of DigitalCommons@University of Nebraska - Lincoln. 


\title{
Landform, soil, and plant relationships to nitrate accumulation, Central Nevada
}

\author{
W.D. Nettleton ${ }^{\text {a,* }}$, F.F. Peterson ${ }^{b}$ \\ a USDA, NRCS, NSSC, Lincoln, NE 68508, United States \\ b University of Nevada, Reno, United States
}

\section{A R T I C L E I N F O}

\section{Article history:}

Received 11 August 2009

Received in revised form 23 July 2010

Accepted 8 August 2010

Available online 22 December 2010

\section{Keywords:}

Holocene soils

Nitrate accumulation

Desert soils

Inset fans

Great Basin

Snowmelt

Denitrification

\begin{abstract}
A B S T R A C T
Nitrate $\left(\mathrm{NO}_{3}^{-1}\right)$ accumulates in Haplocambids and Torrifluvents in inset fan and fan skirt positions in central Nevada. The soils store as much as $17,600 \mathrm{~kg}$ of $\mathrm{NO}_{3}^{-1} \mathrm{~N} \mathrm{ha}^{-1}$ within the upper $208 \mathrm{~cm}$. This paper provides an explanation. These Holocene soils receive $\mathrm{NO}_{3}^{-1} \mathrm{~N}$ from mineralization of organic matter and other $\mathrm{NO}_{3}^{-1} \mathrm{~N}$ sources including snowmelt. The $\mathrm{NO}_{3}^{-1}$ is delivered to soils in the first part of snowmelt in run-off from the higher surfaces. The last part of the melt and the run-off, when sufficient, serve to move the $\mathrm{NO}_{3}^{-1}$ out of the root zone. Winter fat (Krascheninnikovia lanata), the most valuable winter grazing plant in the Great Basin, is the common plant on $\mathrm{NO}_{3}^{-1} \mathrm{~N}$ rich soils. The soils are loamy or sandy and lack horizons restricting water penetration or biological denitrification zones. Hence, some $\mathrm{NO}_{3}^{-1}$ is free to leach deeply past plant roots. Playas, wet floodplains, deeply gullied inset fans and well-developed soils accumulate little $\mathrm{NO}_{3}^{-1}$ except where the latter soils are capped by desert pavements and rarely, if ever become saturated with water. Soils with argillic or petrocalcic horizons or duripans on summits of alluvial fan remnants loose $\mathrm{NO}_{3}^{-1}$ through denitrification, or incorporate it in plants, commonly accumulating less than $50 \mathrm{~kg}^{\circ} \mathrm{NO}_{3}^{-1} \mathrm{~N} \mathrm{ha}^{-1}$. These soils however do accumulate salt as shown by their shadscale saltbush Atriplex confertifolia, bud sagebrush Picrothamnus desertorum, and four-wing saltbush Atriplex conescens shrub cover.
\end{abstract}

Published by Elsevier B.V.

\section{Introduction}

The accumulation of large amounts of nitrate $\left(\mathrm{NO}_{3}^{-1}\right)$ in desert soils again gains attention (Graham, et al., 2008; Walvoord et al., 2003; Jackson et al., 2004; Walvoord et al., 2004). Soil scientists as early as 1906 reported accumulation of $\mathrm{NO}_{3}^{-1}$ in soils of the Great Basin area of the western conterminous United States (Viets and Hageman, 1971). Soil accumulation of $\mathrm{NO}_{3}^{-1}$, not geological accumulation (Boyce et al., 1976; Mansfield and Boardman, 1932), may also be inferred from the work of Gale (1912) near Lovelock and Gerlach, NV. Mansfield and Boardman (1932) reviewed reports of geologic $\mathrm{NO}_{3}^{-1}$ accumulations in 23 states. The $\mathrm{NO}_{3}^{-1}$ was mostly in caves, caliche, and playas. Nitrate accumulates in soils of both hot (Ericksen, 1983) and cold deserts (Claridge and Campbell, 1968; Cameron et al., 1971). In Nevada the Fang Soils have accumulated as much as 17,600 kg/ha (Soil Conservation Service, 1970; Nelson et al., 1973).

$\mathrm{NO}_{3}^{-1}$ occurs in the arid parts of the southwestern United States in soils that have desert varnish and desert pavement (Nettleton et al., 1989; Graham et al., 2008) and accumulate eolian dust (Nettleton et al., 1978). Nitrate in uncultivated deep loess deposits in semiarid areas of Nebraska occurs in concentrations of as much as $87 \mathrm{ppm}$ between depths of 6 to $34 \mathrm{~m}$ (Boyce et al., 1976). Walvoord et al. (2003) points out that this reservoir of bioavailable nitrogen has been

\footnotetext{
* Corresponding author.

E-mail address: dnettleton@inebraska.com (W.D. Nettleton).
}

previously overlooked in studies of global nitrogen distribution. Jackson et al. (2004) found the accumulation of nitrate in Chihuahuan Desert cores is an order of magnitude less than the $\sim 10^{4} \mathrm{~kg}$ of nitrogen per hectare reported by Walvoord et al. (2003). Both Walvoord et al. (2003) and Jackson et al. (2004) however agree that desert subsoil nitrate $\mathrm{NO}_{3}^{-1}$ inventories are spatially highly variable and need additional survey to reduce uncertainty in global explorations.

Other sources of the $\mathrm{NO}_{3}^{-1}$ besides dust have been reported. Mueller (1968) believed the $\mathrm{NO}_{3}^{-1}$ in the North Chilean Desert came from Andes drainage waters. He also considered rainfall following electrical discharge in the atmosphere and the action of nitrifying bacteria on organic matter to be possible sources. Ericksen (1983) believed that most $\mathrm{NO}_{3}^{-1}$ deposits in the Atacama Desert of northern Chile formed by fixation of atmospheric nitrogen by microorganisms in playa lakes and associated moist soils. The $\mathrm{NO}_{3}^{-1}$ would have accumulated when these lakes evaporated to dryness. Present annual rainfall in that desert is about $1-2 \mathrm{~mm}$. Winds later could have spread part of this $\mathrm{NO}_{3}^{-1}$ to soils as dust in the nearby hilly terrain.

Wilson and House (1965) estimated that auroral activity and other geophysical phenomena in the upper atmosphere contributed as much $\mathrm{NO}_{3}^{-1}$ as $0.005 \mathrm{~kg} \mathrm{ha}^{-1}$ year $^{-1}$. Claridge and Campbell (1968) showed that the $\mathrm{NO}_{3}^{-1}$ in Antarctica originated in snowfall and became concentrated as the snow sublimed. Mayewski et al. (1986) found that the $\mathrm{NO}_{3}^{-1}$ concentration in the South Greenland ice core has doubled since about 1950. Snyder and Wullstein (1973) studied the role of desert cryptogams in nitrogen fixation and concluded that lichen blue-green phycobionts, free-living blue-green algae and 


\section{NEVADA}

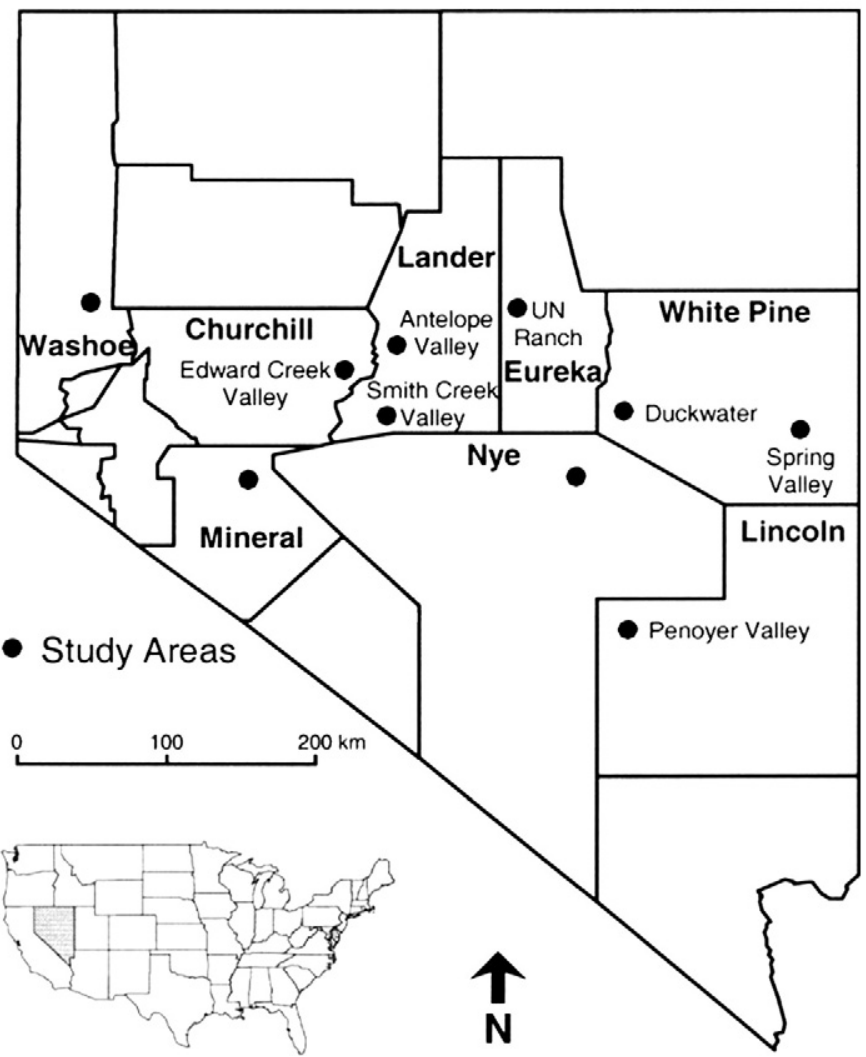

Fig. 1. Location of sampling areas and counties in Nevada in which they occur.

Azotobacter-like organisms were involved, but that total annual nitrogen fixation among desert cryptograms is probably small and related to seasonal moisture. In this paper we investigate the relationship of $\mathrm{NO}_{3}^{-1}$ accumulation in Central Nevada to landform, morphology of the soils, and kind of vegetation supported.

\section{Soils and methods}

We sampled 34 pedons in 8 counties of central Nevada (Fig. 1). The soils are in the Basin and Range Province of the western United States in frigid and mesic soil temperature families and have xeric or torric moisture regimes in which more than half of the precipitation comes as snow. We use landform (physiographic position) terms defined by Peterson (1981) and Schoeneberger and Wysocki (1998) and analytical methods as described and coded by the Soil Survey Laboratory Staff (1996). Saturated pastes (SP) were prepared and electrical conductivity (EC) determined by method $8 \mathrm{~A} 3$ and $\mathrm{NO}_{3}^{-1}$ by methods 6M1c and 6K1c. Cations and anions were checked for chemical balance and analysis repeated when they did not. Statistics and graphics were developed using Statgraphics Plus Version 3 For Windows (Manugistics, Inc, 1997) ${ }^{1}$. A bulk density of $1.47 \mathrm{~g} \mathrm{~cm}^{-3}$ was assumed in calculating $\mathrm{kg}$ of $\mathrm{NO}_{3}^{-1} \mathrm{~N} \mathrm{ha}^{-1}$ for each pedon. The soils are listed by Soil Taxonomy classes (Soil Survey Staff, 2006).

\section{Results and discussion}

Electrical conductivity (EC), nitrate $\left(\mathrm{NO}_{3}^{-1}\right)$, and nitrate nitrogen $\left(\mathrm{NO}_{3}^{-1} \mathrm{~N}\right)$ data for the water extracted from saturated paste for three of the soils and how the total $\mathrm{NO}_{3}^{-1} \mathrm{~N}$ was calculated are in Tables 1-3. Nitrate nitrogen, sampling depth, root distribution, landform, and

\footnotetext{
${ }^{1}$ Use of trade names does not represent an endorsement of products, but is for information purposes only.
}

Table 1

Nitrate and salt data for a Typic Haplocalcid (S81NV011-002), Eureka County, NV, sampled on an inset alluvial fan ${ }^{\mathrm{a}}$.

\begin{tabular}{llllll}
\hline \multirow{2}{*}{$\begin{array}{l}\text { Sample } \\
\text { no. }\end{array}$} & Horizon & $\begin{array}{l}\text { Depth } \\
\mathrm{cm}\end{array}$ & \multicolumn{3}{c}{ Water extracted from saturated paste } \\
\cline { 3 - 6 } \cline { 4 - 6 } & & EC mmhos/cm & $\mathrm{NO}_{3}^{-1} \mathrm{~g} / 1$ & $\mathrm{NO}_{3}^{-1}-\mathrm{N} \mathrm{kg} / \mathrm{ha} / \mathrm{horizon}$ \\
\hline 82231 & $\mathrm{Al}$ & $0-10$ & 0.45 & 0.02 & 2.1 \\
82232 & $\mathrm{Bw} 1$ & $10-30$ & 0.41 & - & - \\
82233 & Bw2 & $30-69$ & 0.44 & - & - \\
82234 & Bk1 & $69-91$ & 9.03 & 2.98 & 940.8 \\
82235 & Bk2 & $91-127$ & 10.99 & 4.20 & 2141.7 \\
82236 & Bk3 & $127-152$ & 12.40 & 4.50 & 1707.0 \\
\hline
\end{tabular}

a $\mathrm{kg} \mathrm{NO}_{3}^{-1}-\mathrm{N} / \mathrm{ha} / 152 \mathrm{~cm}$ soil depth $=4791.6$.

Table 2

Nitrate and salt data for a Typic Torrifluvent (S59NV17-38), Penoyer Valley, Lincoln County, NV, sampled on a shallowly and historically-gullied inset fan ${ }^{\mathrm{a}}$.

\begin{tabular}{llllll}
\hline \multirow{2}{*}{$\begin{array}{l}\text { Sample } \\
\text { no. }\end{array}$} & Horizon & $\begin{array}{l}\text { Depth } \\
\mathrm{cm}\end{array}$ & \multicolumn{3}{l}{ Water extracted from saturated paste } \\
\cline { 4 - 6 } & & & $\mathrm{EC}$ mmhos/cm & $\mathrm{NO}_{3}^{-1} \mathrm{~g} / 1$ & $\mathrm{NO}_{3}^{-1}-\mathrm{N} \mathrm{kg} / \mathrm{ha} /$ horizon \\
\hline 59834 & $\mathrm{C} 1$ & $0-8$ & 0.8 & 0.12 & 6.2 \\
59835 & $\mathrm{C} 2$ & $8-20$ & 0.5 & 0.06 & 4.2 \\
59836 & $\mathrm{C} 3$ & $20-33$ & 0.6 & 0.01 & 0.6 \\
59837 & $\mathrm{C} 4$ & $33-51$ & 0.4 & 0.04 & 58.6 \\
59838 & $\mathrm{CS}$ & $51-109$ & 1.2 & 0.20 & 118.4 \\
59839 & $\mathrm{C} 6$ & $109-132$ & 2.6 & 0.46 & 90.4 \\
59840 & $\mathrm{C} 7$ & $132-163$ & 4.7 & 1.62 & 456.3 \\
59841 & $2 \mathrm{C} 8$ & $163-178$ & 6.1 & 2.36 & 305.0 \\
59842 & 3C9 & $178-198$ & 3.8 & 1.50 & 212.1 \\
\hline
\end{tabular}

${ }^{\mathrm{a}} \mathrm{kg} \mathrm{NO}_{3}^{-1}-\mathrm{N} / \mathrm{ha} / 198-\mathrm{cm}$ soil depth $=1251.8$.

great soil groups are listed in Table 4. Complete soil data and some of the descriptions are available on compact disk (Benham, 1997). The capacity of the soils to retain water between field capacity and the wilting percentage ranges from 2.79 to $33.36 \mathrm{~cm}$ for those we analyzed (Table 5).

Although it seems likely that there is more than one source of the $\mathrm{NO}_{3}^{-1} \mathrm{~N}$ in these soils, herein we propose that mineralization of organic matter accounts for most of the $\mathrm{NO}_{3}^{-1} \mathrm{~N}$ accumulated. The Fang series (S59NV 17-38 of Table 2 is representative) for example produces $392 \mathrm{~kg}$ of dry-weight vegetation/ha/year (350 lb./Ac/year, see Table 3 in Rooke et al., 1968). If we make the following assumptions: (i) an average organic matter production, no increase in soil organic matter content, no loss of $\mathrm{N}$ through run-off, or gaseous loss through denitrification, (ii) plants with a protein content of $10 \%$, a low estimate, and (iii) protein has an $\mathrm{N}$ content of $16 \%$, then the $1251.8 \mathrm{~kg} / \mathrm{ha}$ of $\mathrm{NO}_{3}^{-1} \mathrm{~N}$ stored in the Fang pedon will be added in about 200 years. (1251.8 kg/ha of $\mathrm{NO}_{3}^{-1} \mathrm{~N} / 392 \mathrm{~kg} / \mathrm{ha} / \mathrm{year} / 0.10 / 0.16$ ) (Table VIII, McCreary, 1931 and Bidwell and Wooten, 1925). We consider the Fang soil to be Holocene in age and assumed the time available to be $10 \mathrm{kyr}$.

More $\mathrm{NO}_{3}^{-1} \mathrm{~N}$ needs to become available than the vegetation utilizes for any to accumulate below the rooting zone. The pedon descriptions show that roots reach and determine the upper zone of $\mathrm{NO}_{3}^{-1}$ accumulation (Table 4). Three ways $\mathrm{NO}_{3}^{-1} \mathrm{~N}$ could leach below

Table 3

Nitrate and salt data for a Xeric Petrocalcid (S77NV033-001), White Pine County, NV, on the summit of an erosion fan-piedmont remnant ${ }^{\mathrm{a}}$.

\begin{tabular}{llllll}
\hline \multirow{2}{*}{$\begin{array}{l}\text { Sample } \\
\text { no. }\end{array}$} & Horizon & $\begin{array}{l}\text { Depth } \\
\mathrm{cm}\end{array}$ & & \multicolumn{3}{c}{ Water extracted from saturated paste } \\
\cline { 5 - 6 } & & & EC mmhos/cm & $\mathrm{NO}_{3}^{-1} \mathrm{~g} / 1$ & $\mathrm{NO}_{3}^{-1}-\mathrm{N} \mathrm{kg} / \mathrm{ha} /$ horizon \\
\hline 78 P707 & A & $0-8$ & 1.41 & 0.37 & 29.3 \\
78 P708 & Bw1 & $8-23$ & 0.81 & 0.04 & 7.3 \\
78 P709 & Bw2 & $23-33$ & 0.64 & 0.01 & 1.0 \\
78P710 & 2Bk & $33-46$ & 0.61 & 0.01 & 1.1 \\
78 P711 & 2Bkm & $46-56$ & 1.04 & 0.01 & 0.7 \\
\hline
\end{tabular}

${ }^{\text {a }} \mathrm{kg} \mathrm{NO}_{3}^{-1}-\mathrm{N} / \mathrm{ha} /$ soil depth $=39.4$. 
Table 4

Pedon number, $\mathrm{NO}_{3}^{-1} \mathrm{~N}$ content, sampling depth for nitrate, rooting depth, geomorphic position, and great soil group.

\begin{tabular}{|c|c|c|c|c|c|}
\hline Pedon no. ${ }^{\mathrm{a}}$ & $\mathrm{NO}_{3}^{-1} \mathrm{~N} \mathrm{~kg} \mathrm{ha}^{-1}$ & $\begin{array}{l}\text { Sampling depth } \\
\mathrm{cm}\end{array}$ & $\begin{array}{l}\text { Rooting }{ }^{\mathrm{b}} \text { depth } \\
\mathrm{cm}\end{array}$ & Landform & Great soil group ${ }^{c}$ \\
\hline \multicolumn{6}{|c|}{$\begin{array}{l}\text { Group 1. Inset alluvial fans and fan skirts with well-drained, loamy or sandy soils, without restrictive layers. Vegetative cover is mostly winterfat, black sagebrush, four-wing saltbush, } \\
\text { and galleta }{ }^{\mathrm{d}} \text {. }\end{array}$} \\
\hline S77NV-033-2 & 7645.7 & $56-208$ & 152 & Inset alluvial fan & Typic Haplocambid \\
\hline S80NV-033-1 & 5375.2 & $0-190$ & N.D. ${ }^{f}$ & Inset alluvial fan & Xeric Haplocambid \\
\hline S80NV-033-2 & 4240.5 & $70-190$ & N.D. ${ }^{f}$ & Inset alluvial fan & Xeric Haplocambid \\
\hline S80NV-033-3 & 2.7 & $0-70$ & N.D. ${ }^{f}$ & Inset alluvial fan & Xeric Torriorthent \\
\hline S80NV-033-4 & 1582.9 & $0-220$ & N.D. ${ }^{f}$ & Inset alluvial fan & Xeric Haplocambid \\
\hline S80NV-033-5 & 7415.2 & $70-220$ & N.D. ${ }^{f}$ & Inset alluvial fan & Xeric Haplocambid \\
\hline S80NV-033-6 $6^{\mathrm{e}}$ & 15859.5 & $0-220$ & N.D. ${ }^{f}$ & Inset alluvial fan & Typic Haplocambid \\
\hline S80NV-033-7 & 2137.0 & $70-170$ & N.D. ${ }^{f}$ & Inset alluvial fan & Typic Haplocambid skirt \\
\hline S80NV-021- $1^{\mathrm{e}}$ & 15.5 & $40-90$ & N.D. ${ }^{f}$ & Inset alluvial fan, historically-gullied & Xeric Haplocalcid \\
\hline S81NV011-002 & 4791.6 & 69-152 & 152 & Inset alluvial fan & Typic Haplocalcid \\
\hline S77NV-033-3 & 6102.4 & $68-235$ & 152 & Alluvial fan skirt & Typic Haplocambid \\
\hline S77NV-015-2 & 5510.3 & $60-205$ & 135 & Alluvial fan skirt & Typic Haplocambid \\
\hline S80NV-001-2 & 2659.1 & $40-160$ & 89 & Alluvial fan skirt & Typic Haplocambid \\
\hline S81NV023-030 & 9.5 & $0-152$ & 107 & Alluvial fan skirt & Typic Torripsamment \\
\hline S80NV-001- $1^{\mathrm{e}}$ & 509.4 & $40-120$ & N.D. ${ }^{f}$ & Alluvial fan skirt historically-gullied & Aridic Argixeroll \\
\hline S59NV017-37 & 4193.1 & $0-163$ & N.D. ${ }^{f}$ & Inset fan, historically-gullied & Typic Torrifluvent \\
\hline S59NV017-38 & 1251.8 & $0-198$ & N.D. ${ }^{f}$ & Alluvial fan historically-gullied & Typic Torrifluvent \\
\hline \multicolumn{6}{|c|}{$\begin{array}{l}\text { Group 2. Bypassed alluvial fan and piedmont positions with soils that do not receive run-on from higher surfaces. Vegetative cover is mostly shadscale saltbush, four-wing saltbush, } \\
\text { galleta, bud sagebrush, black sagebrush, Truckee rabbitbrush, big sagebrush, winterfat, and others }{ }^{\mathrm{d}} \text {. }\end{array}$} \\
\hline S59NV-017-34 & 7.4 & $0-168$ & N.D. ${ }^{f}$ & Alluvial fan & Durinodic Natrargid \\
\hline 59NV-017-42 & 15.3 & $0-178$ & N.D. ${ }^{f}$ & Alluvial fan remnant & Typic Natridurid \\
\hline S77NV-033-4 & 4.7 & $20-127$ & 40 & Alluvial fan remnant & Xeric Argidurid \\
\hline S77NV-033-1 & 39.4 & $0-56$ & 46 & Old alluvial fan, summit & Xeric Petrocalcid \\
\hline S81NV001-001 & 0.0 & 163 & 61 & Inset alluvial fan that has been & Xeric gullied Haplocalcid \\
\hline S81NV033-050 & 31.5 & $46-122$ & 46 & $\begin{array}{l}\text { Inset fan remnant, slightly higher than } \\
\text { S77NV033-003 site and separated by } \\
\text { shallow channel }\end{array}$ & Xeric Calciargid \\
\hline S81NV015-001 & 0.0 & 157 & 79 & Alluvial fan summit & Typic Natrargid \\
\hline S81NV011-001 & 386.9 & $0-157$ & 66 & Alluvial fan remnant, summit & Typic Haplocalcid \\
\hline S81NV023-031 & 79.5 & $0-152$ & 152 & Alluvial fan piedmont & Typic Haplocalcid \\
\hline \multicolumn{6}{|c|}{$\begin{array}{l}\text { Group 3. Playas, basins, and associated positions occupied by Aquisalids, Torriorthents, or Haplocalcids. Vegetative cover, some have none, others have black sagebrush, black } \\
\text { greasewood, and suaeda }{ }^{\text {. }} \text {. }\end{array}$} \\
\hline S81NV031-001 & 0.0 & 61 & 0 & Playa & Typic Aquisalid \\
\hline S81NV031-002 & 0.0 & 61 & 0 & Island within playa & Typic Aquisalid \\
\hline S81NV031-003 & 0.0 & 61 & 0 & Near edge of playa & Typic Aquisalid \\
\hline S81NV031-004 & 511.7 & $30-61$ & 0 & Dunes on edge of playa & Typic Torriorthent \\
\hline S81NV033-023 & 3144.9 & $10-163$ & 153 & Fan in basin, summit & Xeric Haplocalcid \\
\hline S81NV001-002 & 3830.1 & $0-152$ & 152 & Flood plain within alluvial flat & Typic Torrifluvent \\
\hline S77NV-015-1 & 182.4 & $76-140$ & 99 & Lacustrine bar & Typic Haplocambid \\
\hline S80NV-011-1 & 107.7 & 147 & N.D. ${ }^{f}$ & Lagoon Typic & Haplocambid \\
\hline
\end{tabular}

a The data for the soils are listed by these pedon numbers on the CD for the laboratory characterization data (Benham, 1997).

b Depth where roots decrease to a few in number.

c Classification system (Soil Survey Staff, 2006).

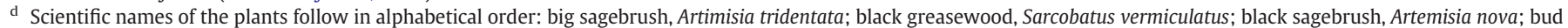

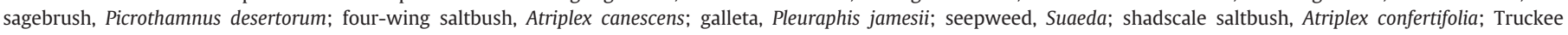
rabbitbrush, Chrysothamnus humilis; and winterfat, Krascheninnikovia lanata.

e Auger samples. Other sites were sampled in backhoe pits.

${ }^{\mathrm{f}}$ Rooting depth not determined.

Table 5

Soil water retention difference (WRD) to depths of $2 \mathrm{~m}$, or to a root limiting horizon, for selected soils ${ }^{\mathrm{a}}$.

\begin{tabular}{llc}
\hline $\begin{array}{l}\text { Soil survey } \\
\text { number }\end{array}$ & Soil taxonomy family & $\begin{array}{l}\text { Total WRD } \\
\mathrm{cm}\end{array}$ \\
\hline S77NV33-1 & $\begin{array}{l}\text { Xeric Petrocalcid, loamy-skeletal, carbonatic, } \\
\text { mesic, shallow }\end{array}$ & 5.25 \\
S77NV33-2 & Typic Haplocambid, coarse-silty, mixed, mesic & 17.16 \\
S77NV33-3 & Typic Haplocambid, coarse-loamy, mixed, mesic & 12.40 \\
S77NV33-4 & Xeric Argidurid, loamy, mixed, mesic, shallow & 2.79 \\
S80NV11-1 & Typic Haplocambid, coarse-silty, mixed, mesic & 33.36 \\
S77NV15-1 & Typic Haplocambid, coarse-loamy, mixed, mesic & 22.03 \\
S77NV15-2 & Typic Haplocambid, coarse-loamy, mixed, mesic & 22.76 \\
\hline
\end{tabular}

a Water available for leaching the profile (monthly sum of precipitation minus potential evapotranspiration) is assumed to be the same as for Ely, White Pine County, Nevada, $7.50 \mathrm{~cm}$

b WRD (water retention difference) is water retained at tensions between $33 \mathrm{kPa}$ and $1500 \mathrm{kPa}$. our sampling depths are from years of above average precipitation, extreme years, or excessive run-on.

We considered the climatic data for Ely to best fit these Nevada soils. That station shows $7.50 \mathrm{~cm}$ of water to be available for profile leaching in an average year (Table 5). The $7.50 \mathrm{~cm}$ received in an average year then likely would not completely wet most of the soils below the depth of roots and not to more than $2 \mathrm{~m}$ even if it all came as one extreme event. In this area, however, we have observed run-off to be common during snowmelt and could account for the deeper leaching in adjacent downslope areas.

\subsection{Relationship of $\mathrm{NO}_{3}^{-1}$ accumulation to landform}

The soils in inset alluvial fan and fan skirt positions accumulate the most $\mathrm{NO}_{3}^{-1} \mathrm{~N}$ followed by those in gullied inset fan and fan summit positions (Fig. 2, Table 4). Of the three groups of landforms, the inset alluvial fans and fan skirts (Fig 2) and gullied inset fans receive run-on 


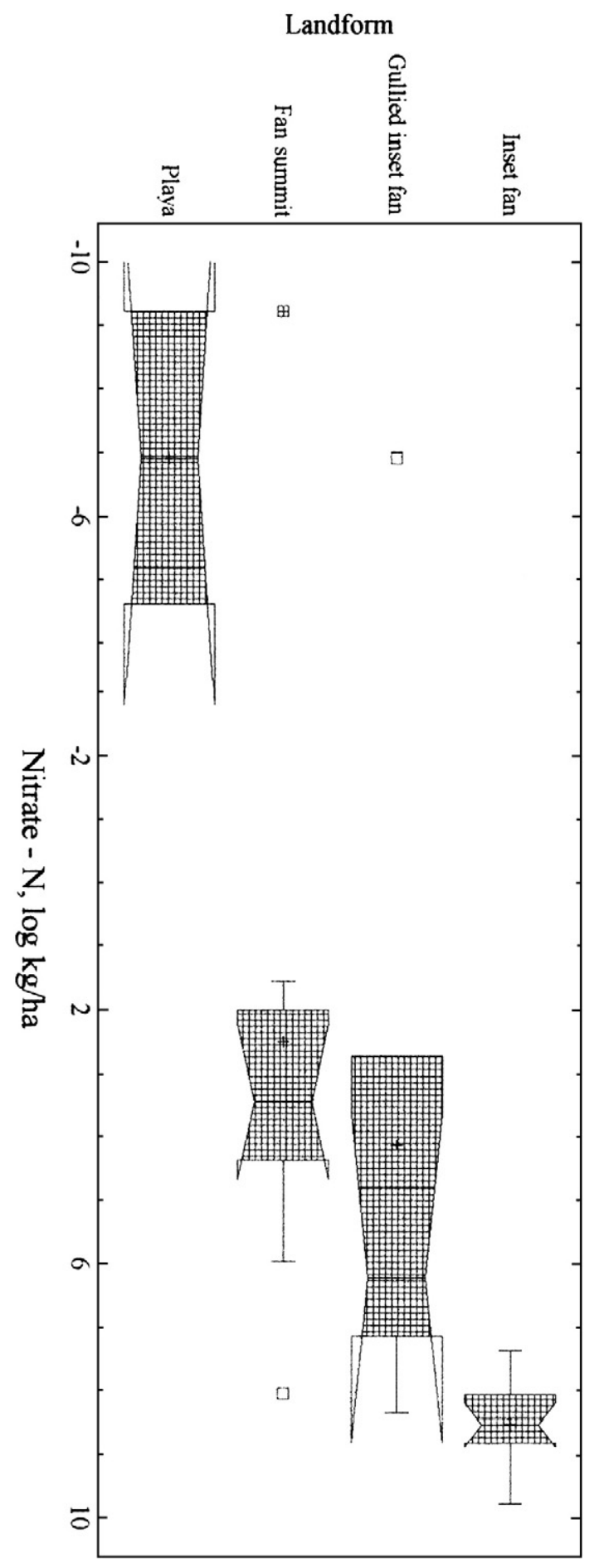

Fig. 2. Box-and-whisker plot of the $\log _{10}$ of the nitrate- $N$ content of the soils in the three landscape positions. The notch represents the median value for the soils in each position.

water. Dissection of the latter apparently resulted in some loss of $\mathrm{NO}_{3}^{-1} \mathrm{~N}$. Without run-on none of the soils receive enough water through precipitation to undergo leaching except the shallow soils like S77 NV 33-3 and 4 (Table 5). Run-off likely also occurs from the soils with duripans, vesicular horizons, and desert pavement.

\subsection{Relationship of $\mathrm{NO}_{3}^{-1}$ accumulation to soil morphology}

Soils with genetic horizons such as duripans and petrocalcic horizons accumulate very little $\mathrm{NO}_{3}^{-1} \mathrm{~N}$ (note the Typic Natridurid,
Xeric Argidurid, and the Xeric Petrocalcid, Table 4). Even the soils with natric and argillic horizons accumulate very little $\mathrm{NO}_{3}^{-1} \mathrm{~N}$ (note the Aridic Argixeroll, Durinodic Natrargid, and Typic Natrargid, Table 4). These results agree with those of Pratt et al. (1972) who found that in 30-m profiles of a long-term fertility trial with citrus that clayey horizons over sands averaged a $52 \%$ loss by denitrification. In their study the textural discontinuities occurred within the first meter.

Most of the other soils are coarse-loamy or coarse-silty and lack horizons that restrict water penetration as inferred from their taxonomic classes (Table 4) and laboratory data available from the National Soil Survey Center (Benham, 1997). One soil, a Torripsamment (S81NV023-030), has accumulated very little $\mathrm{NO}_{3}^{-1}$ within a depth of about $150 \mathrm{~cm}$ although it is in position to receive run-on. It is sandy with a low water holding capacity so that the $\mathrm{NO}_{3}^{-1}$ may have leached to a greater depth than observed in the more uniform medium or coarse-textured soils. Another soil (S77NV015-001) is in a lagoon on an offshore bar and has accumulated only small amounts of $\mathrm{NO}_{3}^{-1}$. It may also be more leached because run-on exceeded the capacity of the soil to hold water. Haplocalcids on summits of alluvial fans contain much more $\mathrm{NO}_{3}^{-1} \mathrm{~N}$ than do the soils with the more strongly developed genetic horizons. This suggests that some $\mathrm{NO}_{3}^{-1} \mathrm{~N}$ has been lost from the more strongly developed soils through biological denitrification since some of these soils have restrictive horizons and would lose little through leaching or lateral subsurface flow above restrictive layers. All of these soils are described as welldrained and have pHs of neutral or higher. However, upon flooding of neutral soils, van Breemen and Brinkman (1978) suggest that after oxygen, $\mathrm{NO}_{3}^{-1}$ is the first to be lost through reduction followed by manganese oxides and then iron oxides.

The Xeric Haplocalcid (S80NV-021-001), Aridic Argixeroll (S80NV001-001), and the Typic Torrifluvents (S59NV-017-037 and 038) have been gullied in historical time (Table 4). Aquisalids in the playa are saturated frequently enough that they accumulate no $\mathrm{NO}_{3}^{-1} \mathrm{~N}$. Presumably any $\mathrm{NO}_{3}^{-1}$ brought in by the water from the higher landscape would be lost through biological denitrification. The dark grayish brown to light olive brown colors ( 2.5 YR 4/2,5/2, and 5/4) of these soils show that some Fe is in the ferrous state (Benham, 1997). The $\mathrm{NO}_{3}^{-1}$ would have been reduced and lost before the Fe.

\subsection{Relationship of $\mathrm{NO}_{3}^{-1}$ accumulation and the water added through run-on to kind of vegetation}

Winterfat (Krascheninnikovia lanata) occurs on the soils of Group 1 landforms (Fig. 3, Table 4). It is a desirable browse for sheep, palatable and nutritious (Holmgren, 1975). Protein content is high (McCreary, 1931). Like other desert shrubs the productivity of winterfat is enhanced by run-on water (Schlesinger and Jones, 1984). It has a deep taproot (Dayton and Associates, 1937, B75-B76) that reaches the soils' deep- $\mathrm{NO}_{3}^{-1}$ and water storage zone. We found the plant to be more common on the soils on Group 1 landforms, but it also occurs on soils on alluvial fan remnants and summits (Fig. 4). We measured significant $\mathrm{NO}_{3}^{-1} \mathrm{~N}$ in all of the soils where winterfat occurs. Some of the other plants of the Goosefoot family, unlike winterfat, accumulate toxic amounts of $\mathrm{KNO}_{3}$ (Dayton, 1960, p. 85).

\subsection{Importance of Snowmelt to $\mathrm{NO}_{3}^{-1}$ accumulation in the soils and sediments of Central Nevada}

Snow is a source of $\mathrm{NO}_{3}^{-1}$ in at least some parts of the world (Junge, 1958; Rogers and Feth, 1959; Wilson and House, 1965; Claridge and Campbell, 1968; Parker and Zeller, 1980; and Mayewski et al., 1986). Snowfall in central Nevada likely also contains $\mathrm{NO}_{3}^{-1}$. Johannessen and Hendriksen (1978) found that $50-80 \%$ of the pollutant load in snow is released with the first $30 \%$ of the meltwater.

The very first meltwater may contain 5 times the concentration of pollutants in the snow pack. This early release would allow more of 


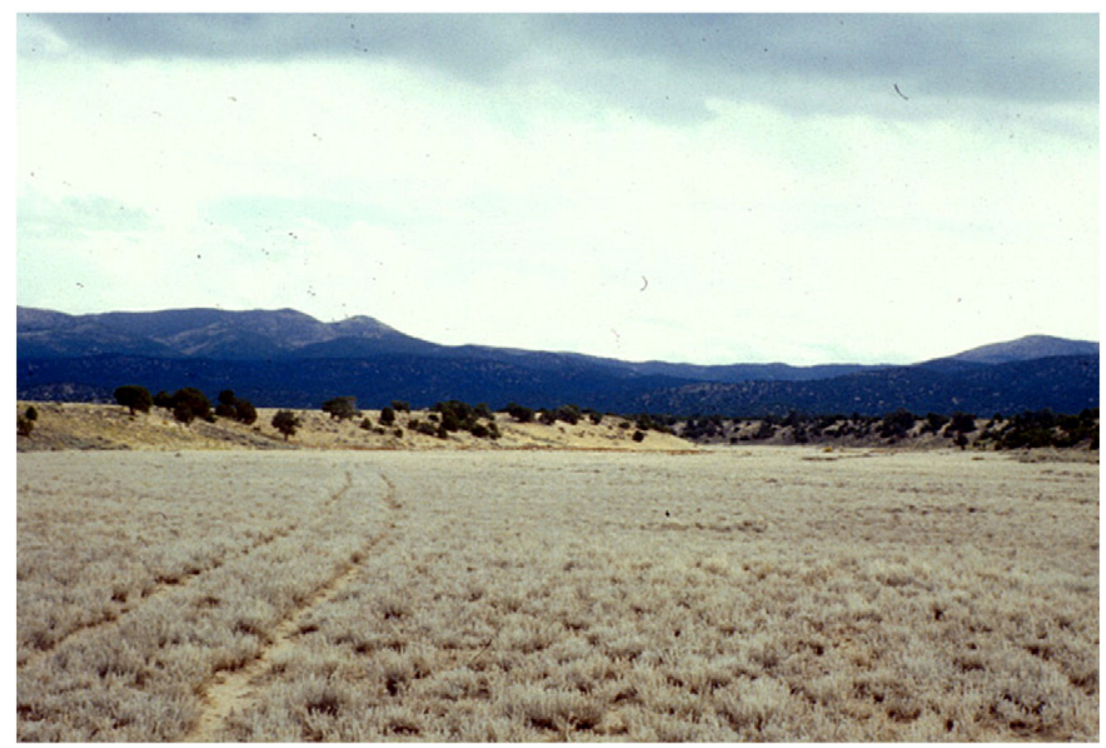

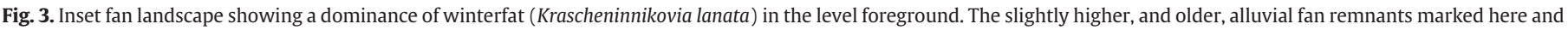
there by juniper divide the foreground from the mountains in the background. The mountains are the source of the alluvial fan sediments.

the $\mathrm{NO}_{3}^{-1}$ to be moved by the later part of the snowmelt past the root zone of the plants. There it could accumulate as long as infiltration did not exceed deep percolation and oxidizing conditions existed. Run-off waters would contain more of the $\mathrm{NO}_{3}^{-1}$ also. Inset fans and fan skirts that receive this $\mathrm{NO}_{3}^{-1}$ charged run-off water then could accumulate large amounts of the $\mathrm{NO}_{3}^{-1} \mathrm{~N}$.

Snowfall is an important part of the precipitation in central Nevada. Any $\mathrm{NO}_{3}^{-1}$ from other sources such as dust (Peterson, 1977), organic matter decomposition, rainfall from thunderstorms occurring at higher elevation (Junge, 1958), or desert cryptograms (Snyder and Wullstein, 1973; Ericksen, 1983) would also be moved to some depth in the soils that receive run-on. Other sources of water such as pluvials of the Pleistocene are not possible for most of these soils, especially those in inset fan positions. Their close relationship to historically gullying suggests that these are Holocene fans and so would neither have received more water nor have supported more productive vegetation than at present (Morrison, 1965).

\subsection{Environmental relationships}

Soils with the most $\mathrm{NO}_{3}^{-1}$ in central Nevada are the well-drained, uniformly-textured ones in inset fan and fan skirt positions that periodically receive run-on water. Those soils that do not receive runon water or have layers restricting water movement mostly do not accumulate $\mathrm{NO}_{3}^{-1}$. Argids and Natrargids with desert pavements are an exception. Although these soils have horizons that restrict water movement, some accumulate $\mathrm{NO}_{3}^{-1}$ in their surface horizons (Nettleton et al., 1989; Graham et al., 2008). Rarely, if ever, do soils with desert pavements become saturated with water for long periods. Possible sources of the $\mathrm{NO}_{3}^{-1}$ in these soils with desert pavements are the nitrogen fixed by microorganisms and plants and to a lesser extent thunderstorm activity, snowmelt, and dust.

The $\mathrm{NO}_{3}^{-1} \mathrm{~N}$ in snow is released with the first snowmelt. We anticipate that the first part of the snowmelt will be leached to greater depth in the soils because it is released at a time when temperatures

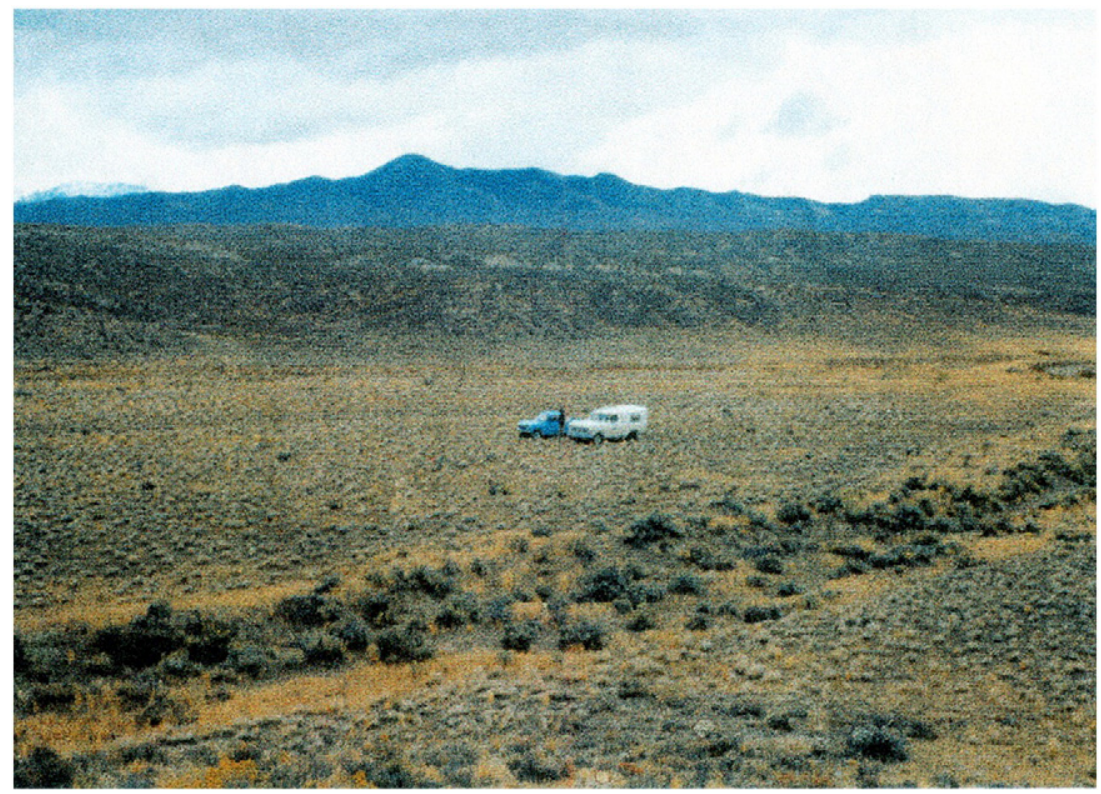

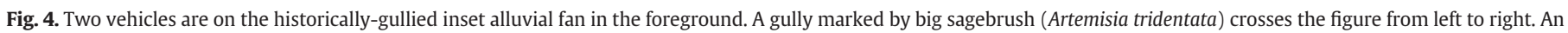
alluvial fan and mountains are in the background. 
are low and water use is small. As the snow continues to melt and spring rains come, the run-on of lower $\mathrm{NO}_{3}^{-1}$ content water forces the higher $\mathrm{NO}_{3}^{-1}$ content water deeper into the soil and beyond the reach of most plants.

Run-off from the surrounding watershed brings the rest of the $\mathrm{NO}_{3}^{-1}$ to the lower part of the landscape. The $\mathrm{NO}_{3}^{-1}$ remaining in the higher parts of the landscape is used by the plants or is leached out of the soils along with most of the salt. In playa and flood plain landscape positions with high water tables reducing conditions may prevent accumulation of $\mathrm{NO}_{3}^{-1}$. Soils in inset fan landscape positions receive enough run-on water to move the $\mathrm{NO}_{3}^{-1}$ below most plant roots, but not out of the profiles. In the other soils in lower landscape positions that do not receive run-on, there is rarely enough water to remove the $\mathrm{NO}_{3}^{-1}$ or salt from the soil and so most of the $\mathrm{NO}_{3}^{-1}$ from eolian dust, snowmelt, etc., is used by the vegetation.

The soils in inset fans of Holocene age in Central Nevada have accumulated $\mathrm{NO}_{3}^{-1} \mathrm{~N}$ at a maximum rate of about $1.8 \mathrm{~kg} \mathrm{ha}^{-1}$ year ${ }^{-1}$. This rate is based on the $17,600 \mathrm{~kg} \mathrm{ha}^{-1}$ accumulated in the Fang soil which is on a Holocene terrace ( $\leq 10,000$ year.). This is a rate of about 1 / 5th to $1 / 7$ th that measured (10-14 $\mathrm{kg} \mathrm{ha}^{-1}$ year $^{-1}$ ) for Iowa soils (Tabatabai and Laflen, 1976). The annual precipitation in the area studied in Nevada is about $1 / 3$ rd that in Iowa, $25-30 \mathrm{~cm} \mathrm{yr}^{-1}$ as compared to $81-$ $86 \mathrm{~cm} \mathrm{yr}^{-1}$, suggesting differences in sources of $\mathrm{NO}_{3}^{-1} \mathrm{~N}$ other than electrical storms. The maximum $\mathrm{NO}_{3}^{-1} \mathrm{~N}$ stored in the central Nevada soils is nearly equal to that Mielke and Ellis (1976) measured below an abandoned feed lot in Nebraska $\left(18,200 \mathrm{~kg} \mathrm{ha}^{-1}\right)$ and much more than that below an active upland feedlot $\left(1840 \mathrm{~kg} \mathrm{ha}^{-1}\right)$, or corn cropland $\left(1100 \mathrm{~kg} \mathrm{ha}^{-1}\right)$. Mielke and Ellis were aware that, before use by modern man, soils in Nebraska, like the ones we analyzed in Central Nevada, contained significant amounts of $\mathrm{NO}_{3}^{-1} \mathrm{~N}$. Our study will make future users of the Nevada soils more aware of native levels of $\mathrm{NO}_{3}^{-1} \mathrm{~N}$.

\section{Acknowledgements}

The late Dr. R.E. Nelson was the leader of this study. In 1973 he along with E.A. Naphan, L. Rooke, and C. D. Henry presented preliminary results at the ASA Meeting in Las Vegas, NV. Dr. Nelson (Nelson et al., 1981) presented a second paper on the work in 1981. A draft of the project was completed in 1988. This paper presents a summary of the data covered in that report.

\section{References}

Benham, E.C., 1997. National Soil Survey Laboratory Characterization Database, [CD-ROM]. USDA-NRCS, National Soil Survey Center, Lincoln, NE.

Bidwell, G.L., Wooten, E.O., 1925. Saltbushes and their allies in the United States. U.S. Dept. Agr. Bul. 134540 pp., illus.

Boyce, J.S., Muir, J., Edwards, A.P., Seim, E.C., Olson, R.A., 1976. Geologic nitrogen in Pleistocene loess of Nebraska. J. Environ. Qual. 5, 93-96.

Cameron, R.E., Lacy, G.H., Morelli, F.A., Marsh, J.B., 1971. Farthest south soil microbial and ecological investigations. Antarctic J. of the U.S. 6, 105-106.

Claridge, G.G.C., Campbell, I.B., 1968. Origin of nitrate deposits. Nature 217, 428-430.

Dayton, W.A., 1960. Notes on Western Range Forbs: Equisetaceae through Fumariaceae. U.S.Gov. Prin. Office, Washington, 25, DC. 254 p.

Dayton, W.A., Associates, 1937. Range Plant Handbook. U. S. Dept. Agr. Forest Service. U.S. Gov. Prin. Office, Washington, DC.

Ericksen, G.E., 1983. The Chilean nitrate deposits. Amer. Scientist 71, 366-374.

Gale, H.S., 1912. Nitrate deposits. U.S. Geological Survey Bull. 523, 19-23.

Graham, R.C., Hirmas, D.R., Wood, Y.A., Amrhein, C., 2008. Large near-surface nitrate pools in soils capped by desert pavement in the Mojave Desert, California. Geology v. 36 (no. 3), 259-262 March 2008.

Holmgren, R.C., 1975. The desert experimental range: description, history, and program. In: Hyder, D.N. (Ed.), Arid shrublands. Proceedings of the Third Workshop of the United States/Australia Rangelands Panel Tucson, Arizona, March 26-April 5. 1973. Soc. for Range Management, Denver, CO, pp. 18-25.
Jackson, R.B., Berthrong, S.T., Cook, C.W., Jobbagy, E.G., McCulley, R.L., 2004. Comment on "A reservoir of nitrate beneath desert soils". Science 304 (5667), 51b.

Johannessen, M., Hendriksen, A., 1978. Chemistry of snow meltwater: changes in concentration during melting. : Water Resources Research, 14. Norwegian Institute for Water Research, Oslo, Norway, pp. 615-619.

Junge, C.E., 1958. The distribution of ammonia and nitrate in rain water over the United States. Trans. Am. Geophys. Union 39, 241-248.

Mansfield, G.R., Boardman, L., 1932. Nitrate deposits in the United States. USGS Bull. 838 $107 \mathrm{p}$.

Manugistics, Inc, 1997. Statgraphics Plus, Version 3. Statistical Graphics Corporation.

Mayewski, P.A., Lyons, W.B., Spencer, M.J., Twickler, M., Dansgard, W., Kocki, B., Davidson, C.I., Honrath, R.E., 1986. Sulfate and nitrate concentrations from a South Greenland ice core. Science 232, 975-977.

McCreary, O.C., 1931. Wyoming forage plants and their chemical composition. Studies No. 9. Wyoming Agr. Exp. Sta. Bull. 18423 p. Illustrated.

Mielke, L.N., Ellis, J.R., 1976. Nitrogen in soil cores and groundwater under abandoned cattle feedlots. J. Environ. Qual. 5, 71-74.

Morrison, R.B., 1965. Quaternary geology of the Great Basin. In: Wright, H.E., Frey Jr., D.G (Eds.), The Quaternary of the United States. Princeton University Press, Princeton, NJ, pp. 265-285.

Mueller, G., 1968. Genetic history of nitrate from Antarctica and Chile. Nature 219, 1131-1134.

Nelson, R.E., Naphan, E.A., Rooke, L., Henry, C.D., 1973. Nitrate in some Entisols and Aridisols of Southern Nevada. Agronomy Abstracts, American Society of Agronomy, Las Vegas, Nevada, p. 116.

Nelson, R.E., Peterson, F.F., Nettleton, W.D., Naphan, E.A., 1981. Distribution of Accumulated Nitrate in Soils of Nevada. Agronomy Abstracts, American Society of Agronomy, Atlanta, and Georgia, p. 202.

Nettleton, W.D., Nelson, R.E. Richmond, D.L, Naphan, E.A. Peterson, F.F, 1978. Contribution of Dust to Salt Accumulation in Some Argids. Agronomy Abstracts, American Society of Agronomy, Los Angeles, CA, p. 172.

Nettleton, W.D., Gamble, E.E., Allen, B.L., Borst, B., Peterson, F.F., 1989. Relict soils of subtropical regions of the United States. In: Bronger, A., Catt, J.A. (Eds.) Paleopedology, Nature and Application of Paleosols, Catena Supplement 16. Catena Verlag, Cremlingen-Destedt, W. Germany, pp. 59-93.

Parker, B.C., Zeller, E.J., 1980. Nitrogenous chemical composition of antarctic ice and snow. Antarctic J. of the U.S. 14, 80-82.

Peterson, F.F., 1977. Dust Infiltration as a Soil Forming Process in Deserts. Agronomy Abstracts, American Society of Agronomy, Los Angeles, CA, p. 172.

Peterson, F.F., 1981. Landforms of the basin and range province defined for soil survey. Tech. Bull. 28 Nevada Agricultural Exp. Sta. 52 pages..

Pratt, P.F., Jones, W.W., Hunsaker, V.E., 1972. Nitrate in deep soil profiles in relation to fertilizer rates and leaching volume. J. Environ. Quality. 1, 97-102.

Rogers, S.M., Feth, J.H., 1959. Chemical constituents in snow from Sierra Nevada California and Wasatch Mountains, Utah. Proceedings, 27th Annual Meeting, Western Snow Conference, Reno, Nevada, pp. 79-87.

Rooke, Lloyd, Langan, L.N., Bagley, D.G., 1968. Soil Survey: Pahranagat-Penoyer Areas, Nevada. USDA, SCS, U.S. Gov. Prin. Office, Washington, DC.

Schlesinger, W.H., Jones, C.S., 1984. The comparative importance of overland runoff and mean annual rainfall to shrub communities of the Mojave Desert. Bot. Gaz. 145 (1), 116-124.

Schoeneberger, P.J., Wysocki, D.A., 1998. Site description. In: Schoeneberger, P.J. Wysocki, D.A., Benham, E.C., Broderson, W.D. (Eds.), Field Book for Describing and Sampling Soils. Version 1.1. USDA, NRCS, National Soil Survey Center, Lincoln, NE, pp. 3-1-3-26.

Snyder, J.M., Wullstein, L.H., 1973. The role of desert cryptograms in nitrogen fixation. The American Midland Naturalists 90, 257-265.

Soil Conservation Service, 1970. Soil Survey Laboratory Data and Descriptions for Some Soils of Nevada. Soil Survey Investigations Report No. 23. U.S.Gov. Prin. Office, Washington, DC.

Soil Survey Laboratory Staff, 1996. Soil Survey Laboratory Methods Manual. Soil Survey Investigations Report No. 42. Version 3.0, January 1996. U.S. Gov. Prin. Office, Washington, DC.

Soil Survey Staff, 2006. Keys to Soil Taxonomy, Tenth Edition. USDA-NRCS-NSSC. U.S Gov. Prin. Office, Washington, DC.

Tabatabai, M.A., Laflen, J.M., 1976. Nitrogen and sulfur content and $\mathrm{pH}$ of precipitation in Iowa. J. Environ. Qual. 5, 108-112.

van Breemen, N., Brinkman, R., 1978. Chemical equilibria and soil formation. In: Bolt, G.H Bruggenwert, M.G.M. (Eds.), Soil Chemistry, A. Basic Elements. Elsevier, New York, pp. 141-170.

Viets Jr., F.G., Hageman, R.H., 1971. Factors Affecting the Accumulation of Nitrate in Soil, Water, and Plants. Agric. Handbook No. 413. U.S. Gov. Prin. Office, Washington, DC

Walvoord, M.A., Phillips, F.M., Stonestrom, D.A., Evans, R.D., Hartsough, P.C., Newman, B.D., Striegl, R.G., 2003. A reservoir of nitrate beneath desert soils. Science 302, 1021-1024

Walvoord, M.A., Phillips, F.M., Stonestrom, D.A., Evans, R.D., Hartsough, P.C., Newman, B.D., Striegl, R.G., 2004. Response to comment on "A reservoir of nitrate beneath desert soils". Science 304 (5667), 51c.

Wilson, A.T., House, D.A., 1965. Chemical composition of South Polar snow. J. of Geophysical Research 70, 5515-5518. 